\title{
Dynamics of globalization: mobility, space and regulation
}

\author{
Ola Söderström, Francisco Klauser, Etienne Piguet, \\ Laurence Crot, Neuchâtel
}

\section{Introduction}

The deep transformations associated with the current phase of globalization have prompted scholars to search for new conceptual, theoretical and methodological approaches to making sense of contemporary socio-spatial (re)configurations. Several authors have emphasised increased mobility as the epitomisation of present times (e.g. MaUrer 2000). Although the recently proclaimed «new mobilities paradigm» (SHELLER \& URRY 2006; URRY 2007) constitutes perhaps the most eloquent instance of this phenomenon, several influent approaches in contemporary social theory are built on more or less explicit assumptions about increasing numbers and varieties of mobility and their role in shaping society. This is true, in particular, for Actor-Network Theory (e.g. LATOUR 2005), theories of cosmopolitanisation (e.g. BECK 2006), assemblage theory (e.g. Collier \& ONG 2005) or anthropological theories of globalization (e.g. ApPADURAI 2006).

Spaces of mobility, in this article, are not seen as frictionless routes through which different flows freely circulate. Rather, they are constituted by a diversity of speeds, obstacles, moorings, power relations and regulations. Understanding globalization geographically, therefore, means developing analytical tools which allow greater understanding and inclusion of the diversity of spaces that shape and are shaped by contemporary societies. Drawing on recent work in this area at the Institute of Geography in Neuchâtel (SÖDERSTRÖM \& CROT 2010), we first propose an analytical framework for the study of the mutual constitution of mobility and society. This is followed by a discussion of three of our research foci related to the study of globalization and how they address the different dimensions identified by this framework.

\section{An analysis of mobility}

The proposal put forward in this section rests on the understanding that the concomitant transmigration of people, objects, ideas, knowledge, practices and capital across multiple borders and spatial scales (local, national and international) continuously reshapes the relationship between social interactions and their regulation. This process of transformation is referred to here as the «mobile constitution of society». The key question, therefore, is how various forms and configurations of mobilities influence such transformations.

To investigate the mobile constitution of society, analytical categories are needed that allow exploration of the relationship between mobility and society. A conceptual framework is presented here that addresses both components of the equation by examining (A) the specific aspects constitutive of various mobilities, and (B) the components of society potentially shaped by these mobilities (Fig. 1).

The definition of (A) aspects constitutive of various types of mobilities follows arguments forwarded by Cresswell (2010). Creswell sees mobility as defined by two sets of factors - mobility as movement defined by its route, velocity, rhythm and spatial scale, and mobility as social construct defined by its meanings, regulations, experiences and competences. The first set recognises that the most distinctive feature of mobility is movement. It acknowledges that movement is not static but has changing properties. Thus, while different types of mobilities are all made of movement, all movements are not identical. To categorise these differences, emphasis is placed first on «what is moving», and then on the description of that movement: characteristics of the route (where is this movement taking place?), velocity and rhythm (at what speed and frequency does this movement occur?) and spatial scale (at what scale is this movement happening?). The second set of factors acknowledges that mobility is more than just movement, it is socially constructed and regulated. Thus, mobility can also be characterised according to particular purposes (what is the purpose of this movement?), meanings (what meaning does it have?) and forms of regulation (what shapes and limits movements?). Further, because humans are involved, mobility can have an emic quality: mobility as experience (how is it experienced?). KaUfMANN (2002) discusses a further emic quality suitable for the research purposes here, that of competences (to what types of movement does one have access?).

Consequently, identifying type of mobility should take both sets of factors into consideration. Through the description and analysis of these various facets of mobility, a deeper understanding of the extent and effects of different physical, symbolic and virtual mobilities could be achieved (e.g. how material and immaterial networks spread within and across national borders; what changes state and society should target to regulate mobilities and their consequences). 


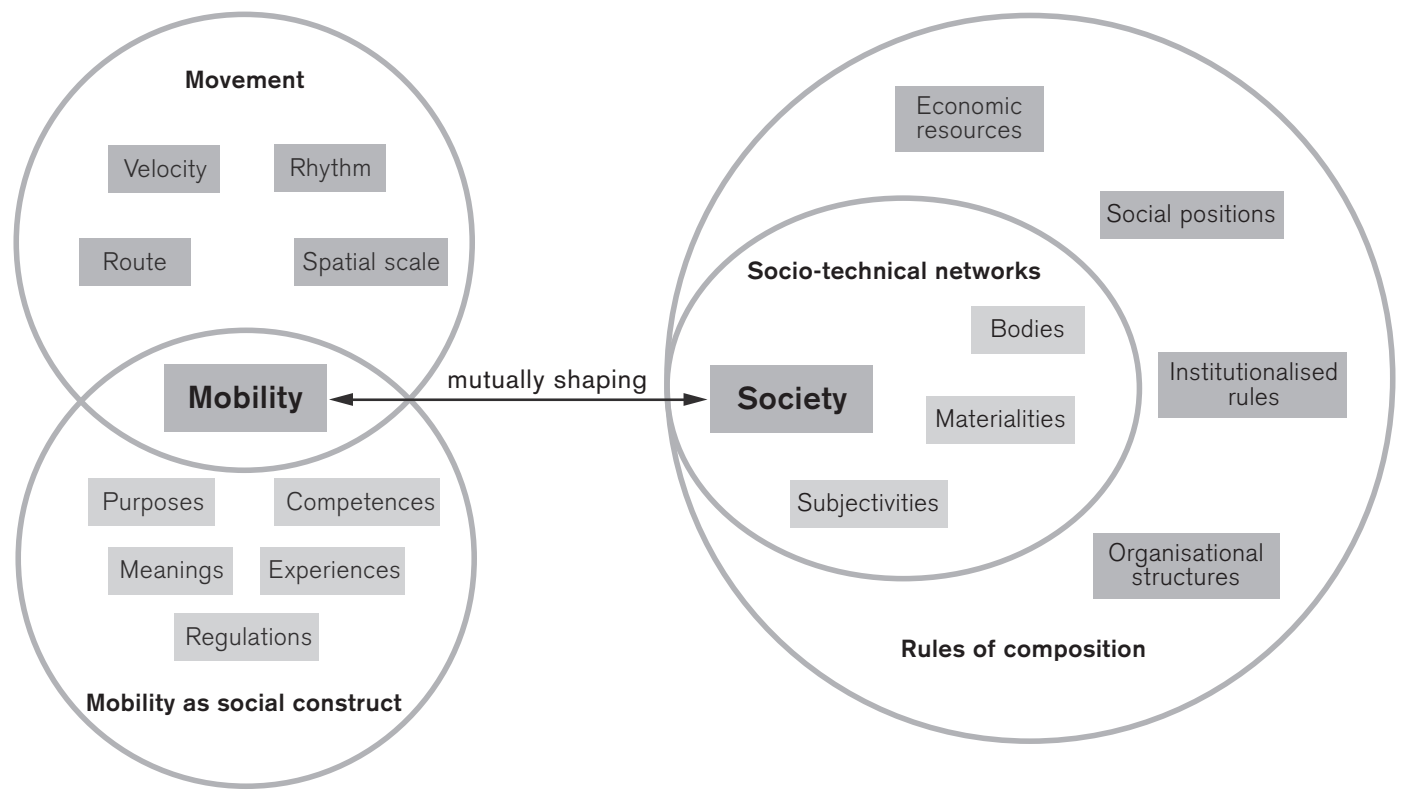

Fig. 1: The mobile constitution of society: an analytical framework

Die mobile Konstitution der Gesellschaft: ein analytisches Gefüge

La constitution mobile de la société: cadre analytique

Concept: L. CROT and O. SöDERSTRÖM; graphics: L. BAUMANN

The other part of the equation discussed above focuses on the components of society potentially shaped by these mobilities (B). This recognition of the socially shaping character of mobility singles out the approach to analysis of mobility presented here over other recent studies. To identify the specific social changes initiated by these mobilities, the various components of society need to be determined first. At a first level of abstraction, society is composed of bodies, subjectivities, material forms (or materialities), and various combinations of relationships among and between them (that can, for instance, be seen as socio-technical networks). These combinations are, however, not constituted in a vacuum but forged by power relations. At a second level of abstraction, society can, therefore, be considered as an assemblage constituted by the above mentioned basic building blocks and by a series of resources and constraints acting as «rules of composition»: economic resources (and their unequal distribution), social positions (and the hierarchies between them), institutionalised rules (such as legal regulations, moral norms and cultural traditions), and organisational structures (e.g. state authorities, industry lobbies, NGOs, and so forth). Society is, therefore, not an organic totality. In fact, to do the concept justice, it would be more appropriate to talk about «the social» instead of «society».
Analysing the mobile constitution of society within this framework means systematically studying constitutive relations between elements in (A) and (B). How, to give a rather classic example, do highly qualified immigrant information and communication technology (ICT) workers with specific professional projects change social positions and institutionalised rules in a given place? As is shown below, the proposed analysis of mobility also opens up the analysis to questions related to other mobilities more rarely addressed in mobility studies, such as the mobility of ideas.

\section{Space, mobility and regulation}

Research in the Institute of Geography at Neuchâtel University (hereafter: IGG) looks at specific aspects of the «mobile constitution of society». Our research focuses, within the broad research agenda described above, on the relations between spaces, mobilities and regulations. In this paper, our ambition is not to provide an exhaustive overview of all the relevant research projects currently underway in Neuchâtel. Rather, we aim to bring together three core themes of our work, in view of highlighting how the IGG - anchored in its concern for an «analytics of mobility» - addresses cur- 
rent issues of globalization. The three core themes are: «international migrations» (1), «urban development and the global city» (2) and «power, space and mobility in the information age» (3). Providing the basic structure of this paper, these three core themes also roughly correspond to the subdivision of the Institute into «population geography», «urban/social geography» and «political geography».

The three notions of space, mobility and regulation (such is our basic assumption), not only run through our discussed core themes, but also offer a worthwhile analytical lens through which to study and to conceptualise current issues of globalization from a mobilityviewpoint. This argument shall be further developed in the conclusive section of this paper. It is in this sense that our paper can also be taken as a point of departure towards a reflection on the conceptual and analytical tools needed for a critical geographical engagement with globalization.

\section{Human migration}

The first core research theme developed at the IGG in relation to globalization, mobility, regulation and space is «human migration». Due to their obvious role in shaping the repartition of populations, human migrations have interested geographers since RATZEL and RAVENSTEIN (BOyLE et al.1998; RoBinson 1996). Up to the end of the 20th century however, migration remained often associated with anomaly; a phenomenon resulting either from a demographic or an economic disequilibrium that it hopefully would contribute towards reducing, or from an external shock: war, political oppression, or natural catastrophe. In both cases, migration was supposed to stop once the society returned to its normal state. In this context, the driver of the evolution of a population was not its mobility but it's propensity to generate a positive balance between birth and death

The idea of migration as a kind of social pathology is not specific to geography. It is implicit in the work of philosophers (ARENDT 1973 [1951]) and historians (LUCASSEN 1996), in the field of refugees studies (MALKKI 1995) and in the hypotheses of the neo-classic economics of migrations (PIGUet \& DE Coulon 2010). More generally, it illustrates quite well the sedentarist metaphysics identified by CRESSWELL regarding mobility (Cresswell 2006).

Starting from these premises, the way migration was seen by geographers progressively changed due to two developments: first, the massive increase in migration flows (from 60 million international migrants to 200 million between 1960 and 2000) and the symmetrical decrease of the birth/death ratio (natural balance) in most countries; second, the growing awareness of the interrelatedness of economic development, globalization and migration. Thus, migration became to be understood more as an intrinsic component of a space of flows rather than as a temporary social anomaly.

As already noted by Adam Smith in the late 18th century, the mobility of people nevertheless remains heavily influenced by the friction of distance. Growth in migration flows hence remains far behind the rise of the other flows such as goods, services and most of all information. Although it increases at a slower rate, its impact is often intensively experienced by societies confronted with the process of globalization - as the contrast between recurrent policy debate around migration flows and debates on other types of flows would seem to indicate. Hence, studying migration parallel to and in connection with other forms of mobility is often given paramount importance.

Three central questions have emerged, in particular in geography, from the new status given to migration in the shaping of spaces of globalization. They illustrate how the three notions of space, mobility and regulation mentioned above interact with the specific topic of migration and are the cornerstones of migration research at the IGG:

- the question of the spatial consequences of migration (space),

- the question of the rationale behind migration flows as well as behind individual decisions to migrate (mobility),

- the question of the regulation of migration and of the power relations associated with it (regulation).

Each of these questions has been considered - in the context of our analysis of various types of mobility (Part A of the equation) - as phenomena defined by route, velocity, rhythm and spatial scale and as social construct defined by meanings, regulations, experiences and competences.

The question of the spatial consequences of migration has been addressed regarding processes of urban segregation (Piguet 1994), urban labour market (Piguet 2000, 2009b) and the constitution of the specific spatialities of immigrant entrepreneurship (ethnic-business) (Piguet 1996). It has also been explored at the interface with another key interest of the Institute: urban change through processes of gentrification in which international migration plays a clear role (RÉrAT et al. 2010a, 2010b).

The question of migration flows is without doubt the most central for us (Fig. 2). Our aim is to highlight the economic, political, socio-cultural and environmental 


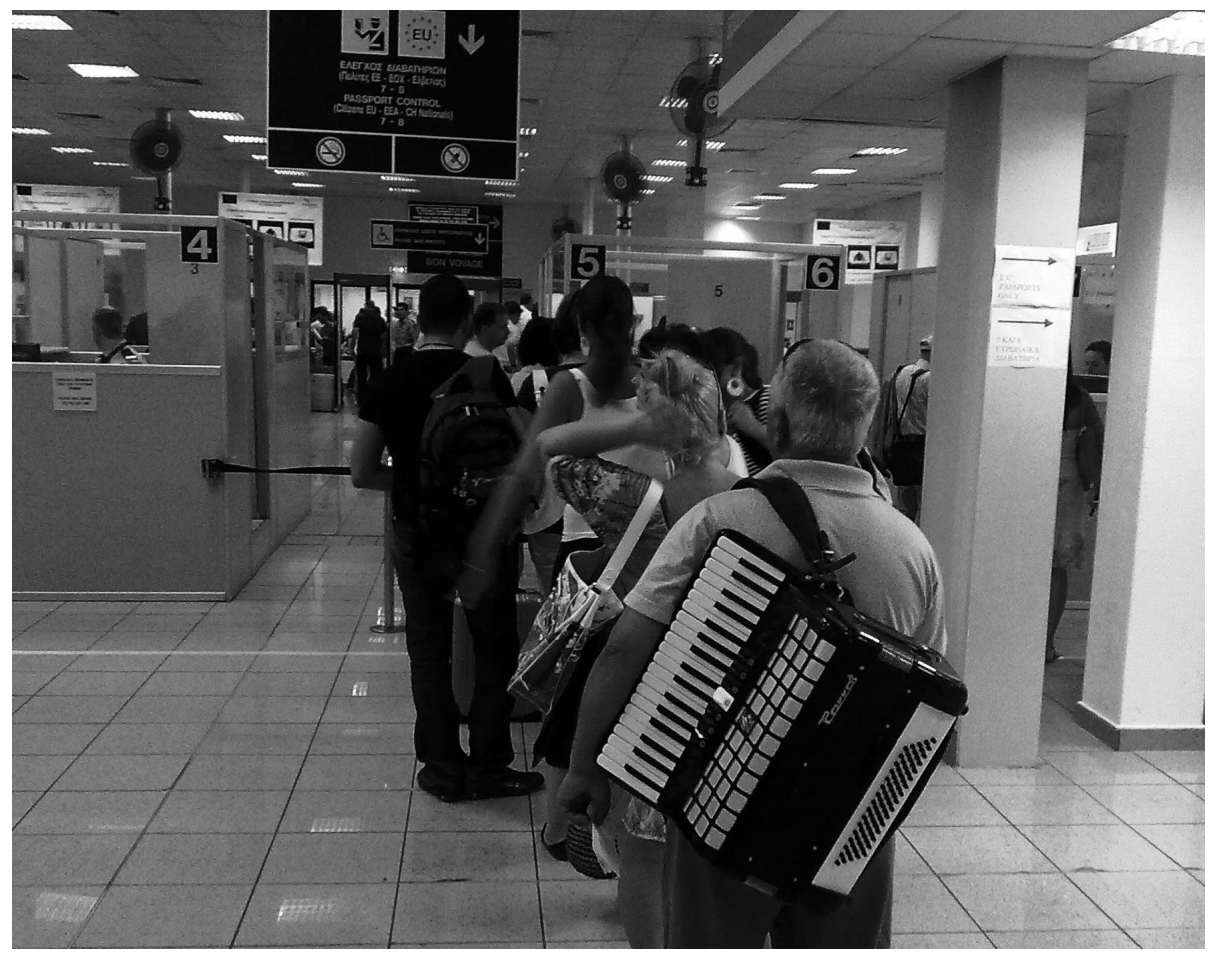

Fig. 2: The Schengen border in Larnaca, Cyprus

Die Schengen-Grenze in Larnaka, Zypern

La frontière de l'espace Schengen à Larnaca, Chypre

Photo: E. Piguet

factors that contribute to migration, and the interactions between these factors. For this reason we have contributed to research on the history of immigration in Switzerland (PIGUET 2009a), the geographical distribution of asylum seekers in Europe (EFIONAYI-MÄDER 2005), the migration of football players (PoLI 2004) and sex-workers (ThiÉvent 2010a, b), and the migration intentions of students in West Africa. We have also recently developed a new focus on the effects of global warming on migration. These issues are studied through the use of case studies (including Bolivia, Iran, Niger and Peru), as well as from a theoretical and epistemological perspective (PIGUET et al. 2011). The IGG's research on this topic will contribute to the IPCC's fifth report on the social consequences of climate change.

Finally, the issue of regulation has been addressed by studies of Swiss and international migration, integration and asylum policies as well as of the uneven geography of access to citizenship among Swiss municipali- ties (Piguet \& WANNer 2000) and the discrimination on the labour market (FIBBI et al. 2003). It is also currently being addressed by $\mathrm{PhD}$ students regarding the regulation of health workers recruitment policies and the interaction between sport and integration.

\section{Urban change}

The second core theme at the IGG, portrayed here from a globalization-viewpoint, can be referred to in general as «urban change». The globalization of cities is a multifaceted process. It involves changes, amongst others, in the order of the world economy, in information and communication technologies, in the political weight of cities, in cultural flows and in migratory movements. Some of these processes have been more thoroughly studied than others. The rise of «global cities» concentrating the headquarters of multinational corporations and highly-skilled labour (SASSEN 1991) has, for instance, been more documented than 
the development of translocal social movements (SмIтH 2003) or issues of built form and urban governance.

The way these changes are studied depends on how the relation between the local and the global is conceived. This relation has been generally considered as a one-way street: cities are globalised as external forces are exerted upon them, a tendency which reinforces conception of local urban realities as victims of abstract, ungrounded and usually impersonal global processes (MASSEY 2005). A less common viewpoint is to explore cities as sources of global phenomena. As a consequence, cities have tended to be considered in themselves and urban change has been studied locally, in situ. Further, the threads relating actions in a city to actions in another potentially quite distant one, have generally been under-researched. This imbalance is problematic, as it leads to a lack of sufficient understanding of social and economic interdependence: of how, for instance, consumption choices in one city affects working conditions in another (MASSEY 2005).

Research on urban globalization at our institute acknowledges, therefore, that the global and the local cannot be posited as two different and hierarchically distinct spheres but should rather be considered as mutually constitutive entities. The methodological consequence of this is that the language of scales, where the local fits in a bigger entity - «the global» (and where cities are thus seen as fitting in nations or in an international order) is less useful than the language of networks (i.e.: connexions, nodes, threads) in order to analyse how cities change (LATOUR 2005; Marston, Paul Jones III \& Woodward 2005). This does not mean, however, that the idea of scale should be discarded altogether, since present political and administrative units have historically been organised accordingly.

In our research, we concentrate on one of the ways of studying cities from a «relational» perspective. We focus in particular on the mobility dimension of models of built form and models of urban development. We study how these models are produced, how they circulate and how they are received. In the terms of the analytical framework described above, we study how these models are constitutive of material, political and cultural changes in globalising cities (Part B of the equation).

\subsection{Mobility and built form}

The mobility of models of urban and architectural form is not a recent phenomenon (FrAMPTON 1992; Hosagrahar 2005). At present, however, an intensification of these processes can be observed, reflecting four phenomena: the development of an entre- preneurial logic in urban politics leading to a more important role of foreign investments (HARVEY 1989), an increase in the mobility of persons (business travel, tourism, international migration) (URRY 2000), the rise of urban marketing (Kearns \& PhILo 1993) and, finally, the internationalisation of architectural offices and journals (CRYSLER 2003; KNOX \& TAYLOR 2005; McNeILl 2009). These different phenomena have contributed to the development of an «import-export» activity in planning and architecture between cities and across national borders.

Our research in this field initially concentrated on identifying the general mechanisms through which these processes take place (Guggenheim \& SöDerSTRÖM 2010). We then focused on three cities, Palermo, Ouagadougou and Hanoi, chosen because of their diversity in location and because of their similarity in cosmopolitanisation processes over the last twenty years: from a period of isolation, due to economic or political circumstances, to a period of reconnection to global flows. A first study looked at the political, material and cultural dimensions of Palermo's cosmopolitanisation since the early 1990s (SÖDERSTRÖM 2010; SÖDERSTRÖM et al. 2009). The subsequent study of Hanoi and Ouagadougou has followed a similar methodology in order to allow for a comparative analysis of three globalising cities focusing on how mobilities and translocal relations shape the transformations of built forms (SöDERSTRÖM 2012a, b; SÖDERSTRÖM et al. 2012) (Fig. 3).

A second and closely related strand of research in this field looks more particularly at the mobility of different models of urban policy and their impact on specific urban contexts.

\subsection{Mobile models and local governance}

In recent years, there has been a growing body of literature on urban policy mobilities (LARNER \& Le Heron 2002; McCann \& Ward 2011; Peck \& Theodore 2001, 2010; WARD 2010). It builds on a critique of traditional work on policy transfers and draws attention to what happens in the mobility process itself: how the content of policies change en route and how «microspaces of persuasion» (MCCANN 2011) - meeting rooms, conferences, site visits, etc. - play an important role in the ways policies are channelled and enacted. In order to get a better understanding of how a «global urban governmentality» (RoBINSON 2011) is produced today, we look at the constitution and mobility of three different models: the sustainable city, traditional neighbourhood development and the US prison model.

The search for sustainable development permeates almost all sectors of contemporary policy making. In the urban realm, urban planning theories and prac- 


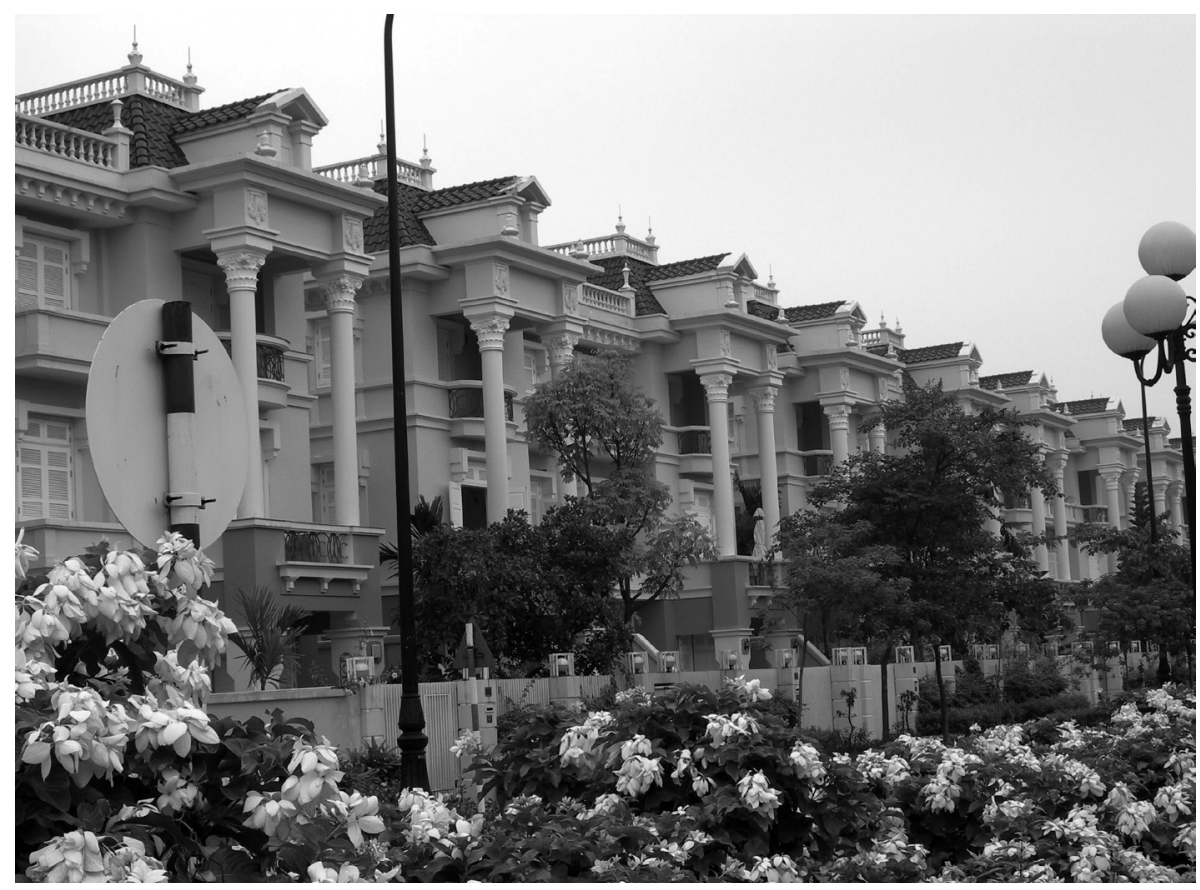

Fig. 3: The gated community as a recently introduced urban type in Hanoi, Vietnam

Eine geschlossene Wohnanlage als kürzlich eingeführter städtischer Siedlungstyp in Hanoi, Vietnam

La communauté fermée: un nouveau type d'habitat urbain à Hanoi, Vietnam

Photo of Ciputra Hanoi International City by O. SöDERSTRöM

tices have been following this trend with traditionalmodernist approaches being supplanted by models of city planning geared towards the attainment of greater sustainability (СRот 2010b; RYDIN 2010). Not all successful experiences of sustainable planning, however, get to travel. Only a few schemes have achieved such widespread recognition as to be replicated by several municipalities across the world. Our research bears on the global mobility of one such «frequent flyer» scheme, known as One Planet Living, and on the politics of its adoption by local authorities before and upon touching ground in host cities (СRоT 2012). The evidence drawn from our case studies - set in Abu Dhabi and San Francisco - emphasises the complex dynamics of policy mobilities and reinforces previous findings regarding the importance of the political games and conditions that underpin transferring processes (Свот 2010c, 2011).

Traditional Neighbourhood Development is part of the movement called New Urbanism. Most research on the «travels» of New Urbanism has concentrated on the implementation of theories and concepts underly- ing the movement (Franklin \& Tait 2002; Freestone 2004; THOMPSON-FAWCETT 1998; THOMPSON-FAWCETT \& Bond 2003), and on the social networks between different urban projects (THOMPSON-FAwCETT 2003; TAIT \& JENSEN 2007). Our research focuses on an aspect which at the moment has been neglected, that of the role of exchanges and circulation in different phases of the movement: its early history, its attempts since the mid 1990's to become global and its implementation in different European cities (DupuIs 2009a, 2009b, 2010, 2011).

The third model explores the international mobility of the US prison model, and more particularly its implementation in Colombia. The research combines a criminological approach of the international mobility of criminal and prison models (for instance NEwBURN \& SPARKS 2004; WACQUANT 1999), and an architectural approach questioning the social and political dimensions of the globalization of this type of building (KING 2004; Markus 1993). Drawing on ethnographic data gathered in the course of an extensive fieldwork in Colombia and the United States, our research high- 
lights how the US prison model entered into conflict with the embedded practices and representations of the old Colombian prison system (DE DARDEL 2010a, 2010b, 2012).

Our work on global trends in urban change also takes Swiss cities into account.

\subsection{Residential mobility, sprawl and gentrification in Switzerland}

Our research in Switzerland focuses on housing. The recent demographic growth of cities and their residential attractiveness have, for example, been analysed in the light of broader socio-demographic trends, such as the second demographic transition (RÉRAT 2012b, 2012c). Gentrification, which has become a major characteristic of urban change in Switzerland, as well as in many other countries (RÉRAT et al. 2010b), has been analysed in relation to the growth of the urban seeking middle class. We have more specifically looked at motivational factors underlying choices made by this middle class group (RÉRAT 2012a) and interpreted residential choices predominantly as means to increase potential of mobility or «spatial capital» (RÉRAT \& LEES 2011).

\section{Power, space and mobility in the information age}

The third major theme of research developed at the IGG, characterised by a strong connection with current questions and challenges of globalization, relates to the mutual imbrications of «power, space and mobility in the information age».

Mobility systems not only shape and enable global flows of people and objects; they also constitute the very Achilles heel of globalization. Thus, in our globalised world the administration, regulation and control of various types of mobilities at local, national and transnational levels is of fundamental importance. Recent developments in this area have been channelled heavily through novel information technology (IT) solutions and developments, enabling increased possibilities of control, regulation and management-at-adistance of everyday forms and formats of mobility. At stake are a vast variety of phenomena, places and scales: from control techniques of transnational mobilities (e.g. through GPS and other «location technologies», radiofrequency indentification (RFID) chips in objects and passports, extended and interlinked databases), to novel solutions for the monitoring and managing of increasingly «smart» intra- and inter-urban infrastructures (from smart electricity grids to electronic ticketing systems and car tracking on motorways).

Research in the IGG provides critical accounts of how, why, and to what effects multi-layered, «surveil- lant assemblages» (HagGerTy \& ERICSON 2000) are coalescing around mobile objects, people (e.g. the shopper, tourist, refugee, suspect passenger, criminal), information and capital (e.g. novel solutions for the monitoring of transnational capital flows). This focus is strongly connected to issues of risk and security. However, and very importantly, it also touches on broader and more fundamental questions regarding the «power geographies of the information age». Three research examples illustrate what we are doing in this area.

Firstly, contemporary issues surrounding the technologically mediated control/regulation of mobility can be exemplified with the Institute's research focusing on the post-9/11 context of the «war on terror». The terrorist attacks in New York (11 September 2001), Madrid (2004) and London (2005) all focused on, and worked through, intra- and inter-urban mobility systems (trains, buses, airplanes). Thus, as security and terrorist risks are widely seen to colonise and operate through the everyday mobility systems of highly urbanised societies, so the post-9/11 «war on terror» is seen to emphasise the imperatives of securing civil infrastructures and mobility systems against lurking threats. Here, the challenges of managing massive scales and densities of circulation within systems of mobility mix uncomfortably with the dilemmas involved in trying to anticipate threats and to manage public perception of risk. Thus, at the interface of two apparently opposed worlds - the necessary mobility of objects, people, information and capital on the one hand, and the control and (if necessary) restriction of these mobilities on the other - new forms of regulation, management and surveillance-at-a-distance are defined by a set of practices and techniques facing the key challenge of balancing and combining the needs and demands of mobility and security (AMOORE 2006).

Recent work in the Institute has addressed this issue from an empirically informed viewpoint, focused on the aviation sector (KLAUSER 2009) and on sport mega-events (KlaUSER 2010, 2011). Both cases are characterised by a strong global mobility-dimension at their core: airports, due to their function as entrance/ departure points and as hubs of global flows of people and objects; sport mega-events, due to their function as hubs of mass movement and circulation towards/ across the host cities/nations. Furthermore, both cases also illustrate the globalization of contemporary risk and security issues (terrorism, hooliganism, organised crime, etc.), and the increasing globalization of security partnerships, legislations and best-practices in this field.

A second, more recent field of investigation in the Institute focuses on the socio-technical mediations 
of inter- and intra-urban mobilities, through the topic of «smart», or «smarter» cities. Smarter cities must be understood as a wide and disparate range of efforts which aim at the creation of the «future city» as an interconnected, digitised and «technologically empowered» (IBM 2010) system of connections, processes and flows. Thus, the topic is intrinsically bound-up with mobility-issues: at their very core, efforts towards smarter cities imply a world of perfect ordering and regulation-at-a-distance that relies, fundamentally, on the surveillance and coding of urban circulations into software (GRAHAM 2005). This issue is also currently being addressed by a $\mathrm{PhD}$ project recently launched at the IGG, focussing on «intelligent urban mobility», mediated by («smart») iphone applications. Yet such processes of ordering and software sorting are never neutral, whether the collection, classification and analysis of data aim at greater efficiency, speed, convenience or security.

The IGG's explorative research in this field aims to highlight a number of critical issues - and to assess their potential implications for individuals and social groups - arising from the organizational settings and coalitions of authority underpinning current efforts towards smarter cities. It does so through the empirical investigation of several initiatives devoted to the elaboration of novel best practices and technologies for smarter cities.

A third topic, also related to what we have named «urban policy mobilities» above, seeks to investigate the transnational circulation, sharing and appropriation of public-private surveillance- and securityrelated knowledge and practices, and looks at the ways in which these fuse and blend in specific geographical locales. This theme also connects with research that challenges conventional notions of how the state exercises authority over space and mobility in an age of neo-liberalism and globalization (thus leading back to the three concepts of «regulation», «mobility» and «space»). To address these issues, airports and sport mega-events are, again, very interesting examples at hand.

\section{Conclusions}

In all three research fields described above, we interpret globalization as characterised by different and interdependent mobilities. After briefly summarising the fields again, the article turns here to a final discussion on how the combination of the concepts «space», «regulation» and «mobility» can lead to a fuller picture of the whole through the different, yet complimentary perspectives they offer on an analysis of the process of globalization.
The first research theme, «human migration», was portrayed in its concern with the socio-spatial effects of migration (space) on different social, temporal and spatial scales; with the reasons and modalities of migrations (human mobility); and with the implications, problems and challenges of governing and regulating human migrations (socio-political regulation).

The second core research theme, «urban change», emphasised the key role played today by different and interdependent mobilities (and especially the mobility of ideas) on the production of urban spaces. It connected urban development with the continuously expanding global arena of policy exchanges and emphasised that urban change is, as a consequence, the result of a complex entanglement of global and local forms of regulation.

The description of our third core theme, «power, space and mobility in the information age», emphasised the risk and security issues associated with mobility systems (human mobility); the «making» of increasingly standardised «spaces of surveillance» (mobility of ideas and technologies); the power implications of surveillance systems and practices (socio-technical regulation); and the (socio-) spatial logics and implications of the increased socio-technical mediations of social life (space).

In all three cases, we interpret globalization as characterised by different and interdependent mobilities. Common to each core theme is thus the idea that an analysis of mobility must pay particular attention to the materiality of spaces and the power of regulations.

The concept of «space», in particular, offers a semantic field that complements in interesting ways the meanings associated with «mobility». This does not imply that the two concepts are mutually exclusive. Rather, it is argued here that the concepts present two complementary perspectives on the process of globalization. Whilst «mobility» stresses the connections and flows between entities and places, «space» brings to the fore the intrinsic voluminosity and materiality of the places produced by, and in turn producing, globalised mobilities.

In our research on human migration, for example, we are interested not only in the movements of migrants, but also in the spaces themselves, from which these movements originate, through which they lead and at which they arrive. Likewise, our work on urban policy mobilities not only focuses on the actual circulation of policies, but also on the spaces created by the local reception and adaptation of moving objects, people, ideas and forms of expertise. Finally, our work on security issues associated with mobility systems not only 
focuses on the monitoring, filtering and management of intra- and/or inter-urban flows of various kinds, but also on the social perceptions, experiences and practices associated with the thereby created spaces of security.

The concept of «regulation», in turn, offers a worthwhile analytical lens to emphasise both the power issues (per definition implied by the concept) and the regulatory challenges associated with the complex imbrications between space and mobility. Our work on human migration, security/surveillance and urban change is concerned in very important ways with policy making (as a socio-political form of regulation) in its opportunities and modalities, but also in its inherent problems and power issues. In our work on urban change, we show on the one hand that regulations travel with models of urban development, and on the other hand, that these regulations both change along the way and (often) collide with existing regulatory frameworks, leading to the shaping of quite specific «globalised localities».

If, as we suggest, globalization can be seen as a process of constitution of society through mobility, we also see it as a field of tensions: between fluidity and turbulence, standardisation and diversity, power and resistance. It is along these lines that research on globalization in our department will be developed in the years to come.

\section{References}

Amoore, L. (2006): Biometric borders: governing mobilities in the war on terror. - In: Political Geography 25, 3:336-351.

APPADURAI, A. (2006): Fear of small numbers: an essay on the Geography of Anger. - Durham, London: Duke University Press.

ArEndT, H. (1973 [1951]): The origins of totalitarianism. - New York: Harcourt Brace Jovanovich.

Beck, U. (2006): Cosmopolitan vision. - Cambridge: Polity Press.

Boyle, P.J., Halfacree, K. \& V. Robinson (1998): Exploring contemporary migration. - London: Longman.

Collier, S.J. \& A. ONg (2005): Global assemblages, anthropological problems. - In: COLLIER, S.J. \& A. ONG (eds): Global assemblages: technology, politics, and ethics as anthropological problems. - Malden, MA: Blackwell: 3-21.

Cresswell, T. (2006): On the move - mobility in the modern Western world. - London: Routledge.

Cresswell, T. (2010): Towards a politics of mobility. In: Environment and Planning D: Society and Space 28, 1: 17-31.

CROT, L. (2010a): Transnational urban policies: «relo- cating» Spanish and Brazilian models of urban planning in Buenos Aires. - In: Urban Research \& Practice 3, 2: 119-137.

CRот, L. (2010b): Green communities and neighbourhood planning. - In: CoHEN, N. (ed.): Green cities. London: Sage.

CROT, L. (2010c): Lost in translation: la mondialisation d'un modèle de gouvernance urbaine. - In: GéoRegards - Revue Neuchâteloise de Géographie 3: 25-37.

CROT, L. (2012): Planning for sustainability in nondemocratic polities: the case of Masdar City (under submission at Urban Studies, copies available directly from the author).

Crysler, G.C. (2003): Writing spaces: discourses of architecture, urbanism and the built environment. London: Routledge.

De DARDEl, J. (2010a): The international circulation of the US prison model: impacts in Colombia. - Paper presented at the Association of American Geographers' Annual Meeting, Washington, D.C., 17th April 2010.

De Dardel, J. (2010b): How the US prison model traveled to Colombia: methodological aspects on the mobility of a penitentiary confinement system. - Paper presented at the MOVE-EUROQUAL International Seminar «Mobile Constructions of Society», Neuchâtel, 6th June 2010.

De DARdel, J. (2012): Resisting «bare life»: prisoners' agency in the new prison culture era in Colombia. - In: Conlon, D., Moran, D. \& N. Gill: Carceral Geographies: mobility and agency in spaces of incarceration and detention. - London: Ashgate (forthcoming).

Dupuis, B. (2009a): Le mouvement du New Urbanism et le paysage urbain: la circulation d'une doctrine urbanistique. - In: Articulo - Journal of Urban Research 2: http://articulo.revues.org/1133 08.05.2012.

Dupuis, B. (2009b): «A swarm tactic». La circulation des principes du New Urbanism. - In: Revue économique et sociale 67, 2: 151-155.

Dupuis, B. (2010): Gouvernance urbaine et modèle néo-traditionnel: le partenariat public-privé du Val d'Europe. - In: Géo-Regards - Revue Neuchâteloise de Géographie 3: 39-53.

Dupuis, B. (2011): Genèse, réseaux et performativité de l'urbanisme néo-traditionnel. - In: Lieux communs - les modèles urbains entre courants, références et performances 14: 16-41.

EFIONAYI-MÄDER, D. (2005): Trajectoires d'asile africaines: déterminants des migrations d'Afrique occidentale vers la Suisse. - Neuchâtel: Swiss Forum for Migration and Population Studies.

FibBi, R., Kaya, B. \& E. Piguet (2003): Le passeport ou le diplôme? Etude des discriminations à l'embauche des jeunes issus de la migration. - Rapport de Recherche 31, Neuchâtel: Forum suisse pour l'étude des migrations. 
Frampton, K. (1992): Modern architecture: a critical history. - London: Thames and Hudson.

Franklin, B. \& M. TAIT (2002): Constructing an image: the urban village concept in the UK. - In Planning Theory 1, 3: 250-272.

Freestone, R. (2004): The Americanization of Australian planning. - In: Journal of Planning History 3, 3: 187-214.

Graham, S. (2005): Software-sorted geographies. - In: Progress in Human Geography 29, 5: 562-580.

Guggenheim, M. \& O. SöDerström (2010): Introduction: mobility and the transformation of built form. In: GugGenheim, M. \& O. SöDERSTröm (eds): Re-shaping cities: how global mobility transforms architecture and urban form. - London: Routledge: 3-19.

Haggerty, K. \& R. Ericson (2000): The surveillant assemblage. - In: British Journal of Sociology 51, 4: 605-621.

Harvey, D. (1989): From managerialism to entrepreneurialism: the transformation in urban governance in late capitalism. - In: Geografiska Annaler, Series B, Human Geography 71, 1: 3-17.

HosagraHar, J. (2005): Indigenous modernities: negotiating architecture and urbanism. - London: Routledge.

IBM (2010): Smarter cities with IBM software solutions. - IBM online: ftp://public.dhe.ibm.com/software/ $\mathrm{ch} / \mathrm{de} / \mathrm{multimedia/pdf} /$ transcript-smarter-cities-withibm-software-solutions-eng.pdf 08.05.2012.

Kaufmann, V. (2002): Re-thinking mobility: contemporary sociology. - Aldershot: Ashgate.

Kearns, G. \& C. Philo (eds) (1993): Selling places: the city as cultural capital, past and present. - London: Pergamon Press.

KING, A.D. (2004): Spaces of global cultures: architecture urbanism identity. - London: Routledge.

KLAUSER, F. (2009): Interacting forms of expertise in security governance: the example of CCTV surveillance at Geneva International Airport. - In: British Journal of Sociology 60, 2: 279-297.

Klauser, F. (2010): Splintering spheres of security: Peter Sloterdijk and the contemporary fortress city. In: Environment and Planning D, Society and Space 28, 2: 326-340.

KLAUSER, F. (2011): The exemplification of «fan zones»: mediating mechanisms in the reproduction of best-practices at Euro 2008. - In: Urban Studies 48, 15: 3203-3219. KnOX, P. \& P. TAYLOR (2005): Toward a geography of the globalization of architecture office networks. - In: Journal of Architectural Education 58, 3: 23-32.

LARner, W. \& R. Le Heron (2002): The spaces and subjects of a globalizing economy: a situated exploration of method. - In: Environment and Planning D, Society and Space 20, 6: 753-774.

Latour, B. (2005): Reassembling the Social. An introduction to Actor-Network-Theory. - Oxford: Oxford University Press.
LUCASSEN, L. (1996): A blind spot: migratory and travelling groups in western European historiography. In: Holmes, C. (ed.): Migration in European history (vol. 1). - Cheltenham: Edward Elgar: 476-504.

MalkKI, L.H. (1995): Refugees and exile: from «refugee studies» to the national order of things. - In: Annual Review of Anthropology 24: 495-523.

Markus, T.A. (1993): Buildings and power: freedom and control in the origin of modern building types. London: Routledge.

Marston, S., Paul Jones III, J. \& K. Woodward (2005): Human geography without scale. - In: Transactions of the Institute of British Geographers 30: 416-432.

Massey, D. (2005): For space. - London: Sage.

MAurer, B. (2000): A fish story: rethinking globalization on Virgin Gorda, British Virgin Islands. - In: American Ethnologist 27, 3: 670-701.

McCANN, E. (2011): Urban policy mobilities and global circuits of knowledge. Towards a research agenda. - In: Annals of the Association of American Geographers 101, 1: 107-130.

McCann, E. \& K. Ward (2011): Mobile urbanism. Cities and policymaking in the global age. - Minneapolis: University of Minnesota Press.

McNeILl, D. (2009): The global architect. Firms, fame and urban form. - London: Routledge.

Newburn, T. \& R. Sparks (eds) (2004): Criminal justice and political cultures: national and international dimensions of crime control. - London: Willan.

Peck, J. \& N. Theodore (2001): Exporting workfare/ importing welfare-to-work: exploring the politics of third way policy transfer. - In: Political Geography 20, 4: 427-460.

Peck, J. \& N. Theodore (2010): Mobilizing policy:models, methods, and mutations. - In: Geoforum 41, 2: 169-174.

Piguet, E. (1994): L'immigration et ses espaces: géographie des populations d'origine étrangère à Lausanne. - In: Geographica Helvetica 2, 3: 63-72.

Piguet, E. (1996): Les commerces étrangers dans l'espace urbain: le cas de Lausanne. - In: WicKER, H.-R. (ed.): L'altérité dans la société: migration, ethnicité, Etat. - Zürich: Seismo: 75-92.

Piguet, E. (2000): Immigration and the urban labour market. - In: Urban PlanNing - City of VienNa \& OCDE/OECD (eds): Migration and sustainable urban development. - Werkstattbericht 30a, Vienna: City of Vienna: 61-64.

Piguet, E. (2009a): L'immigration en Suisse - soixante ans d'entrouverture ( 2 édition entièrement mise à jour). - Lausanne: Presses polytechniques et universitaires romandes.

Piguet, E. (2009b): Migrations et travail décent. - In: International Journal of Multicultural Societies 11: 36-50.

Piguet, E. \& G. De Coulon (2010): La volonté de migrer. Etat des lieux théorique. - In: Working Paper MAPS 11. 
Piguet, E. \& P. WANner (2000): Les naturalisations en Suisse: différences entre nationalités, cantons et communes, 1981-1998. - Neuchâtel: Office fédéral de la statistique.

Piguet, E., Pécoud, A. \& P. De Guchteneire (eds) (2011): Migration and climate change. - Paris: UNESCO, Cambridge: Cambridge University Press.

PoLI, R. (2004): Les migrations internationales des footballeurs: trajectoires de joueurs camerounais en Suisse. - Neuchâtel: Centre international d'études du sport - CIES.

RÉRAT, P. (2012a): Gentrifiers and their housing choice. Characteristics of the households living in new developments in Swiss cities. - In: Environment and Planning A, 44, 1: 221-236.

RÉRAT, P. (2012b): The new demographic growth of cities. The case of reurbanization in Switzerland. - In: Urban Studies 49, 5:1107-1125.

RÉRAT, P. (2012c): Housing, compact city and sustainable development: some insights from recent urban trends in Switzerland. - In: International Journal of Housing Policy (forthcoming).

RérAT, P. \& L. LeEs (2011): Spatial capital, gentrification and mobility: evidence from Swiss cities. - In: Transactions of the Institute of British Geographers 36, 1: 126-142.

Rérat, P., SöDerström, O. \& E. Piguet (2010a): New forms of gentrification: issues and debates (Special issue editorial). - In: Population, Space and Place 16, 5:335-343. Rérat, P., Söderström, O., Piguet, E. \& R. Besson (2010b): From urban wasteland to new-build gentrification: the case of Switzerland. - In: Population, Space and Place 16, 5: 335-343.

Robinson, J. (2011): The spaces of circulating knowledge: city strategies and global urban governmentality. - In: MCCANN, E. \& K. WARD (eds): Mobile urbanism. Cities and policymaking in the global age. - Minneapolis: University of Minnesota Press: 15-40.

Robinson, V. (ed.) (1996): Geography and migration. Cheltenham: Edward Elgar.

Rydin, Y. (2010): Governing for sustainable urban development. - London: Earthscan.

Sassen, S. (1991): The global city. - Princeton, N.J.: Princeton University Press.

SHELLER, M. \& J. URRY (2006): The new mobilities paradigm. - In: Environment and Planning A 38, 2: 207-226. SмITH, M.P. (2003): Transnational urbanism: locating globalization. - Malden: Blackwell.

SöDERSTRÖM, O. (2010): Forms and flows in the contemporary transformations of Palermo's city centre. - In: GugGENHEIM, M. \& O. SÖDERSTRÖM (eds): Re-shaping cities: how global mobility transforms architecture and urban form. - London: Routledge: 189-209.

SöDERSTRÖM, O. (2012a): What traveling urban types do. - In: SöDerström, O., Ruedin, D. \& G. D'Amato (eds): Critical mobilities. - London: Routledge (forthcoming).
SöDERSTRÖM, O. (2012b): Cities in relation. - Oxford: Blackwell (forthcoming).

SöDERSTRÖM, O. \& L. CROT (2010): The mobile constitution of society: rethinking the mobility-society nexus. In: Working Paper MAPS-MOVE, http://www2.unine. ch/maps/page28639_fr.html 08.05.2012.

Söderström, O., Fimiani, D., Giambalvo, M. \& S. Lucido (2009): Urban cosmographies. - Roma: Meltemi.

SöDerströM, O., Dupuis, B. \& P. Leu (2012): Translocal urbanism: how Ouagadougou strategically uses decentralised cooperation. - In: OвRist, B., Veit, A. \& E. Maсамо (eds): Living in the African City (forthcoming).

TAIT, M. \& O.B. JENSEN (2007): Travelling ideas, power and places: the case of urban villages and business improvement districts. - In: International Planning Studies 12, 2: 107-127.

ThiÉvent, R. (2010a): Temporal dimensions of cabaret dancers' circular migration to Switzerland. - In: HARDY, K., Kingston, S. \& T. SAnders (eds): New sociologies of sex work. - Surrey: Ashgate: 149-163.

ThiÉVent, R. (2010b): Emotions, international division of labor and circulation: the case cabaret dancers in Switzerland. - In: HeIKKILÄ, E. \& B. YeoH (eds): International marriages in the time of globalization. - New York: Nova Science Publishers: 137-153.

Thompson-Fawcett, M. (1998): Léon Krier and the organic revival within urban policy and practice. - In: Planning Perspectives 13, 2: 167-194.

Thompson-Fawcett, M. (2003): A new urbanist diffusion network. The Americano-European connection. - In: Built Environment 29, 3: 253-270.

Thompson-FawcetT, M. \& S. Bond (2003): Urbanist intentions for the built landscape: examples of concept and practice in England, Canada and New Zealand. In: Progress in Planning 60, 2:147-234.

URRY, J. (2000): Mobile sociology. - In: British Journal of Sociology 51, 1: 185-203.

URrY, J. (2007): Mobilities. - Cambridge: Polity Press. Wacquant, L. (1999): Les prisons de la misère. - Paris: Raison d'Agir Éditions.

WARD, K. (2010): Entrepreneurial urbanism and business improvement districts in the State of Wisconsin: a cosmopolitan critique. - In: Annals of the Association of American Geographers 100, 5: 1177-1196.

\section{Abstract: Dynamics of globalization: mobility, space and regulation}

Recent research at the Institute of Geography in Neuchâtel emphasises the pivotal status of mobility in the dynamics of globalization. Drawing on work in mobility studies, the article presents a basic analytical framework suitable for studying the «mobile constitution of society». It argues more specifically that the relationship between mobility, space and regulation offers a worthwhile analytical focus for exploring current 
issues of globalization from the viewpoint of mobility. The article presents current research at the Institute that explores this interrelation, focusing on three main fields: «human migration», «urban change» and «power, space and mobility in the information age». It argues that globalization can be seen as a process of constitution of society through mobility, and as such a field of tensions: between fluidity and turbulence, standardisation and diversity, power and resistance.

Keywords: globalization, mobility, space, regulation

\section{Zusammenfassung: Dynamik der Globalisierung: Mobilität, Raum und Regulierung}

Das Geographische Institut der Universität Neuenburg untersucht und versteht Mobilität als zentrale Dimension aktueller Globalisierungsprozesse. Der vorliegende Artikel entwickelt einleitend, in Anlehnung an die Mobility Studies, ein allgemeines Analyseraster zum Studium der «mobilen Konstitution der Gesellschaft». Darauf aufbauend wird speziell der analytische Nutzen der Begriffe Mobilität, Raum und Regulation hervorgehoben, um aktuelle Entwicklungstendenzen der Globalisierung aus einer MobilitätsPerspektive zu behandeln. Auf dieser theoretischen Grundlage lässt sich die aktuelle Arbeit des Instituts in drei Forschungsrichtungen einteilen: «Migration», «Stadtentwicklung» sowie «Raum und Macht im Informationszeitalter». Abschliessend wird die Rolle der Begriffe Mobilität, Raum und Regulation in allen drei Forschungsrichtungen dargelegt.

Schlüsselwörter: Globalisierung, Mobilität, Raum, Regulation

\section{Résumé: Les dynamiques de la mondialisation: mobilité, espace et régulation}

Les recherches actuelles conduites à l'Institut de Géographie de l'Université de Neuchâtel se concentrent sur l'importance cruciale de la mobilité dans les dynamiques de la mondialisation. En s'appuyant sur les études de la mobilité, cet article présente un cadre analytique susceptible d'étudier la «construction mobile de la société». L'article montre que la relation entre la mobilité, l'espace et la régulation fournit un angle d'approche particulièrement approprié à l'exploration des enjeux contemporains de la mondialisation, considérée à travers le prisme de la mobilité. Il décrit les recherches actuelles conduites à l'Institut, qui s'articulent autour de trois thèmes: migrations; changement urbain; et pouvoir, espace et mobilité dans la société de l'information. L'article montre que la mondialisation peut être appréhendée comme un processus de constitution de la société par la mobilité. Ce processus conduit à certaines tensions, notamment entre fluidité et turbulence, standardisation et diversité, et pouvoir et résistance.

Mots-clés: mondialisation, mobilité, espace, régulation

Prof. Dr. Ola Söderström, Dr. Francisco Klauser, Prof. Dr. Etienne Piguet, Dr. Laurence Crot, Institut de Géographie, Université de Neuchâtel, Espace LouisAgassiz 1, CH-2000 Neuchâtel, Switzerland. e-mail: ola.soderstrom@unine.ch francisco.klauser@unine.ch etienne.piguet@unine.ch laurence.crot@unine.ch

Manuskripteingang/received/manuscrit reçu le 29.8.2011

Annahme zum Druck/accepted for publication/accepté pour publication: 14.5 .2012 